\title{
Legibility of Small-Scale Industrial Sector in Promoting Social-Economic Development of Informal Settlements: Case of Mlalakuwa in Kinondoni, Dar es Salaam
}

\author{
Jacob Lutta ${ }^{*}$, Yves Schoonjanss ${ }^{1}$, Aldo Lupala ${ }^{2}$ \\ ${ }^{1}$ Department of Architecture, KU Leuven Campus Sint-Lucas, Ghent, Belgium \\ ${ }^{2}$ School of Spatial Planning and Social Sciences, Ardhi University, Dar es Salaam, Tanzania \\ Email: *lutjet.lutta@gmail.com
}

How to cite this paper: Lutta, J., Schoonjans, Y., \& Lupala, A. (2021). Legibility of Small-Scale Industrial Sector in Promoting Social-Economic Development of Informal Settlements: Case of Mlalakuwa in Kinondoni, Dar es Salaam. Current Urban Studies, 9, 677-693.

https://doi.org/10.4236/cus.2021.94040

Received: September 23, 2021

Accepted: November 26, 2021

Published: November 29, 2021

Copyright $\odot 2021$ by author(s) and Scientific Research Publishing Inc. This work is licensed under the Creative Commons Attribution International License (CC BY 4.0).

http://creativecommons.org/licenses/by/4.0/ (c) (i) Open Access

\begin{abstract}
Small-scale industries constitute essential elements in accelerating the flourishing of the economy in towns. Cities in global south countries are witnessing an expansion to an unprecedented scale. The growth of cities is accompanied by the emerging of small-scale industrial activities like handcraft industry, car repair workshops, sewing, furniture making, which act as economic pivots for urban proliferation. They represent an important factor for the provision of employment to a large number of people living in urban centres. The investigation was done through a case study of small-scale industrial activities running at informal settlements to provide a better understanding of the roles of small-scale industries that promote community quality of lives at Mlalakuwa informal settlements. This paper aims at providing an understanding of the diversity of small-scale industrial sectors as a potential tool for the development of collective spaces usage at Mlalakuwa informal settlement. Smallscale industrial activities are well known in informal areas in the city of Dar es Salaam because they provide opportunities for boosting local social-economic activities and improving the community's livelihoods. The results show that more than $50 \%$ of the residents engaged with small-scale industries to sustain their daily lives. Whereby $70 \%$ of the settlement growth development at Mlalakuwa is the result of small-scale industrial activities. There has been a good opportunity for the authorities to have an integrated revenue collection between formal and informal economic sources if SSI activities will be positively considered one of the economic hubs for the betterment of the city's development.
\end{abstract}




\section{Keywords}

Urbanization, Collective Spaces, Informal Settlements, Social-Economic, Growth, Tanzania

\section{Introduction}

Small-scale industries are sub-sectors of the business sector, which play an important role in improving the national GDP (Ahmed, 2006; UNEP, 2016). Restructuring of the economic sector in the developing countries is the result of switching out from the agricultural sector to the industrial mode of production (IBID). It is argued that cities in sub-Saharan Africa urbanization have been decoupled from economic growth due to improper strategic plan of national policies and less effort done in planning practices (Pacione, 2001; Henderson, 2002). Sub-Saharan Africa has the highest percentage of the working poor who depend on small-scale industrial sectors as a major source of income generation (Dixon et al., 2001; ILO, 2005a).

Nigeria had economic structural challenges in the 1980s as a result of the global recession, including foreign exchange scarcity, unemployment, inflation, mounting governmental debts, low productivity, and general social problem (Aikoye, 1989; Francis, 2009; Obi, 2015). In 1982, the federal government enacted the economic stabilization act with the intention of restructuring the economy (IBID). In an attempt to reduce poverty, therefore, initiatives from various individuals and small-scale industrial activity groups were established (Kigbu \& Maku, 2015). The existing regulations and planning methods aimed at small-scale industries have a detrimental impact on how efficiency is practiced in informal settlements (McGranahan \& Brown, 2015; Wijaya et al., 2019). On the other hand, the city's planning is rarely considered SSI ${ }^{1}$ operating in informal settlements while their existence gives positive results in taxes and levies collection in many cities in the country.

The aspiration of low-income communities is to overcome the financial challenges that are not fulfilled by authorities by building up strong collective assets which will help to construct better economic infrastructures to sustain their lives in urban environments (Ogundiji, 2006; Onibokun et al., 1987). This gives an opportunity for informal residents to establish various types of SSI to overcome the social and economic barriers erected by development actors in the sense of transforming informal settlements (Schmidt-Traub, 2015; Shand et al., 2017).

Many scholars accentuate that countries in the global south countries need substantial investments to solve the social, economic, and environmental challenges that informal dwellers face in urban centers (ILO, 2005b; Magalhaes \& Eduardo, 2007). Communities who are living in extreme environmental conditions are trying their best to catch up with the environment in many ways to fill the gaps left be- 
tween formal and informal development (Chakrabarti, 2001; Edusah, 2013).

The population growth in many cities in developing countries is driving up demand for land to establish new housing and economic infrastructures. As many authorities are often shown unwilling to provide economic infrastructures in informal settlements due to insufficient development budget from the central government (Amiri \& Lukumwena, 2018; Jahani, 2020). This demonstrates the loss of management strategies of many authorities have resulted in many informal residents having alternative solutions fighting against poverty reduction (King \& Dovey, 2013; UN-Habitat, 2016). The inability of formal sectors in Ghana pushed low-income communities into SSI sectors which operated in many informal settlements that were found to be leftover from the city's development process (Osei-Boateng \& Ampratwum, 2011).

Before the 1990s, Tanzania was among the African developing countries with vibrant industries operated under Small Industries Development Organization ${ }^{2}$ (Mtatifikolo, 1998; Mwang'onda et al., 2018). Due to unstable economic sectors and political changes, all mills went down (Skarstein \& Wangwe, 1986). The privatization policy gave out negative results that led to rapid city urbanization and an increased amalgam of small-scale industries to meet the demand for employment opportunities in the country (Moshi, 2001; Marwa, 2015). However, the urbanization trend is the result of informal settlements and the booming of informal industrial sectors in many developing cities (Allen, 1977; Huchzermeyer, 2004). The informal settlement became an economic hub for low-income communities to drive their social-economic activities for their daily lives (Amiri \& Ghanbari, 2016).

Within the informal settlements, there is some space that needs to be understood their existence, importance and how they contribute to the operation of small-scale industrial activities (Avermaete et al., 2006). Scholars often depict the importance of public space, common space describing their contribution to the liveliness of that space (Lupala, 2002; Nguluma, 2003; Mbisso \& Kalugila, 2018). Manuel De sola Morales contrived the term collective space where community get accessibility for social, economic and political issues (de Sola Morales, 1992; Schoonjans \& Zhang, 2020). Scheerlinck (2013) depicted collective space as a point of intersection for the community to share common values (Scheerlinck, 2013). This can be also linked to informal settlements as well where collective spaces seem to be an important space for various activities including the operation of Small-Scale industries.

Today the growing small-scale industrial activities in informal settlements areas are witnessing taking place in unpredictable ways (Gaillard \& Beernink, 2001). The economic sectors have not grown enough to accommodate a number of people in cities including Dar es Salaam (Sheuya, 1997; Bernstein, 1982; Diochon, 2003). The small-scale industrial sector has become an immediate tool to assist informal settlements communities to solve unemployment challenges that happen to exist for many decades (Sheuya, 1997). However, little has been paid at-

${ }^{2}$ Small Industries Development Organization in Tanzania is well known by SIDO. 
tention to the operation of small-scale industrial sectors in informal settlements. In this manner, there is a need to investigate the legibility of small-scale industrial activities in informal settlements, and the extent to which economic activity clusters add values to collective space in the flourishing of the urban economy. This paper aims to analyze the types of small-scale industries and their locations, as well as to examine their potential modes of operations, including all systems of the supply chain that enhance the spatial development of collective space at Mlalakuwa informal settlements.

\section{Methods}

The study employed qualitative methods such as interview methods and focused group discussion in gathering data to obtain an understanding of the present conditions. Primary data was gathered through a focused group discussion held with Mlalakuwa residents, who engaging with SSI activities at Mlalakuwa informal settlement from April to August 2021. Interviews were also held with six groups of Small-Scale Industries at different locations. Then latter were sampled through snow ball method while the former given the nature of their activities were accidentally or conveniently sampled. Sampling was necessary to this research as (Selltiz et al., 1977) opined:

(...) "It is rarely necessary to study all the people in a group in order to provide an accurate and reliable description of the attitudes and behaviour of its members. More often than not, a sample of the population to be studied is sufficient" (Selltiz et al., 1977).

The researchers sampled the SSI in a purposive manner by identifying 52 respondents with four different user groups that were interviewed. The focus was on SSI located at Mlalakuwa informal settlements which were established by individuals or small groups to examine how they battle in exploring the spaces for the purpose of establishing the SSI activities. The choice was also based on individual person who could start with a very confined space with a little capital and started to grow up time after time. The primary data was supplemented by secondary data sources such as articles, surveys and other studies conducted on the emerging of economic infrastructure which led to spatial growth at Mlalakuwa informal settlements.

\subsection{Case Study}

The research case study is Mlalakuwa informal settlement located in Kinondoni district, Dar es Salaam region. Mlalakuwa is one of the prominent informal neighbourhoods which is surrounded by six major activity centers, namely: Mwenge military hospital, Mwenge woodcarvers market, DDC Mlimani park ${ }^{3}$, a retail ${ }^{3}$ DDC Mlimani park is a business park with social halls and shops owned by Dar es Salaam Development Cooperation (DDC) as a business entity from Ilala city council. The Music band 'Mlimani Park Orchestra' came to be sponsored by DDC therefore, the name changed to DDC Mlimani Park Orchestra. 
center (Mlimani City Mall), University of Dar es Salaam, and Ardhi University. Mlalakuwa is an informal settlement with a diverse social and economic population, including students, faculty and non-academic staff, vendors, landlords, nurses, and retired army officers (Kalugila \& Mbisso, 2018; Lutta et al., 2021).

The pressure to search for collective spaces for various economic and social activities is increasing every day to mitigate the number of inhabitants and non-inhabitants looking for services. According to URT (2013), Mlalakuwa has a population of about 19,453 inhabitants, of which 9950 are men and 9503 are women. Nevertheless, it is a settlement that keeps on receiving new people with the aspiration of connecting the community to social, economic, and physical development potential (Teyanga \& Mrema, 2018; Kalugila \& Mbisso, 2018; Tesha, 2020). Mlalakuwa is located in the western part of Dar es Salaam city and is well connected to other parts of the city through Sam Nujoma Road, Morogoro and Bagamoyo highways (Figure 1). The current challenges at Mlalakuwa, as in other informal settlements, include the operation of SSI, which leads to an emerging diversity of collective spaces such as car repair workshops, furniture workshops, steel workshops, and sewing workshops. This is the concern to study how the informal settlement is legible to attract the operation of SSI activities which led to the development of Mlalakuwa neighbourhood.

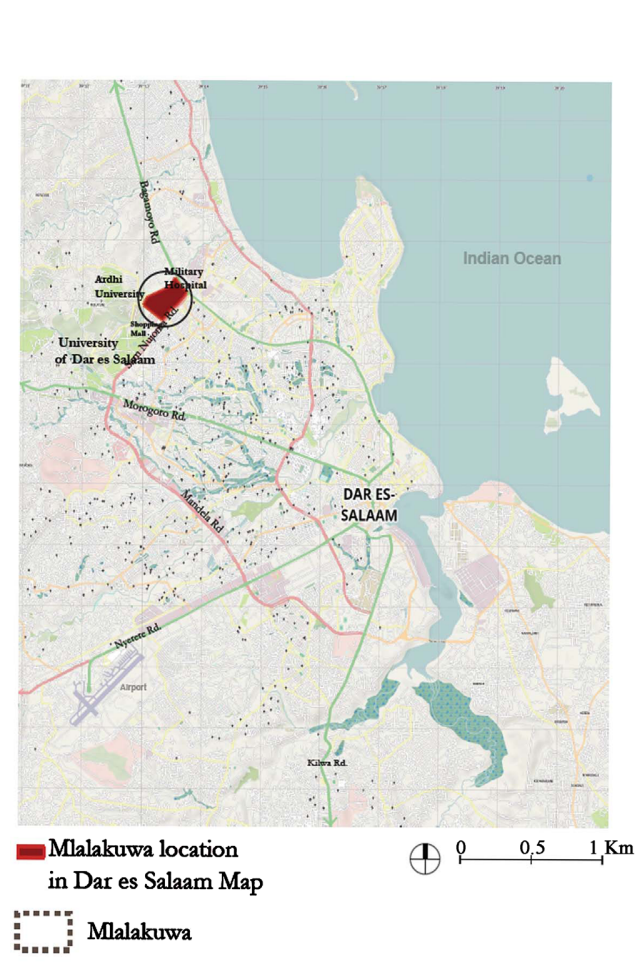

Source: Adapted from Google map 2019.

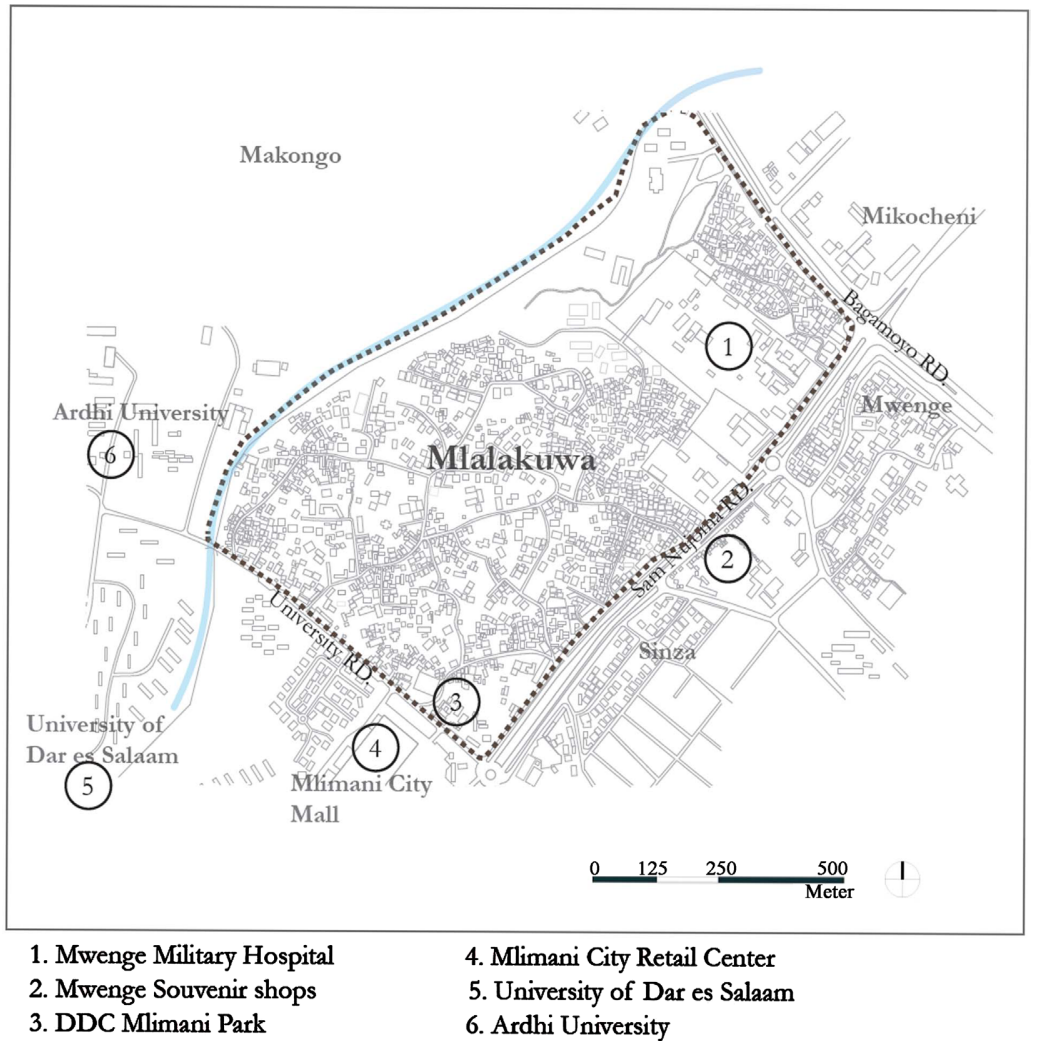

3. DDC Mlimani Park
5. University of Dar es Salaam

6. Ardhi University

Figure 1. Dar es Salaam map showing the location of Mlalakuwa informal settlement. 


\section{Results}

\subsection{Analysis of the Legibility of Small-Scale Industries}

There are 6 main types of Small-Scale Industries, which make a total of 56 SmallScale Industries found in the Mlalakuwa area this is includes: 8 car repair garages, 11 sewing workshops, 22 wood processing and furniture workshops, 2 bakeries and 11 steel workshops and 2 Cement and sand blocks (Table 1). However, it has been found that most of the SSI is located near the main roads. i.e., Bagamoyo road, Sam-Nujoma road and University main road. Figure 2 depicting SSI located in interior streets of the Mlalakuwa. However, car repair workshops, wood processing and furniture workshops were seen to be located close to main streets. An interview with a customer at car repair workshop narrated:

(...) "I often prefer to use this garage close to the main road because it's easier to access. As you can see, there are many of potholes in the streets of Mlalakuwa neighbourhood. During the rainy season, the potholes are full of water and it becomes difficult to drive on interior streets. And of course, along the main road we can get other services, like bars and shops, which are everywhere" 4 .

This implies that SSI activities which located along or near by the main roads they have privilege of getting more customers because of flexibility and proximity to main roads. The study revealed that they are three car repair workshops located near to the University road, four along Sam Nujoma road and two car repair workshops on the side of Bagamoyo road which seems to be convenient for most of the customers at Mlalakuwa and adjoining settlements easily access for services.

Table 1. Analysis of the SSI utilization Capacity at Mlalakuwa.

\begin{tabular}{lllc}
\hline S/N Type of SSI & Location/Street & Number of SSI \\
\hline 1 & Sewing (Tailoring) & $\begin{array}{l}\text { Survey Street, Along University Road. Sam Nujoma and Others Located } \\
\text { to Unknown Streets }\end{array}$ & 11 \\
2 & Car Repair Workshops & $\begin{array}{l}\text { University Road, Lufungila Street, Bagamoyo Road and Other Located to } 8 \\
\text { Unknown Streets }\end{array}$ \\
3 & Wood Processing and Furniture & $\begin{array}{l}\text { University Road, Sam Nujoma Road, Bagamoyo Road and Other } \\
\text { Located Unknown Streets }\end{array}$ & 22 \\
& Workshop & University Road Only & 2 \\
5 & Bakery & Steel/Welding & Different Streets \\
6 & Cement and Sand Block & One Located at Lufungila and Other Located to Unknown Street & 2
\end{tabular}

Source: Adopted from (Kalugila \& Mbisso, 2018), (Tesha, 2020) and updated during Fieldwork, 2020.

${ }^{4} \mathrm{An}$ interview held on April 2021 with a customer at one of the car repair workshop at Mlalakuwa. 


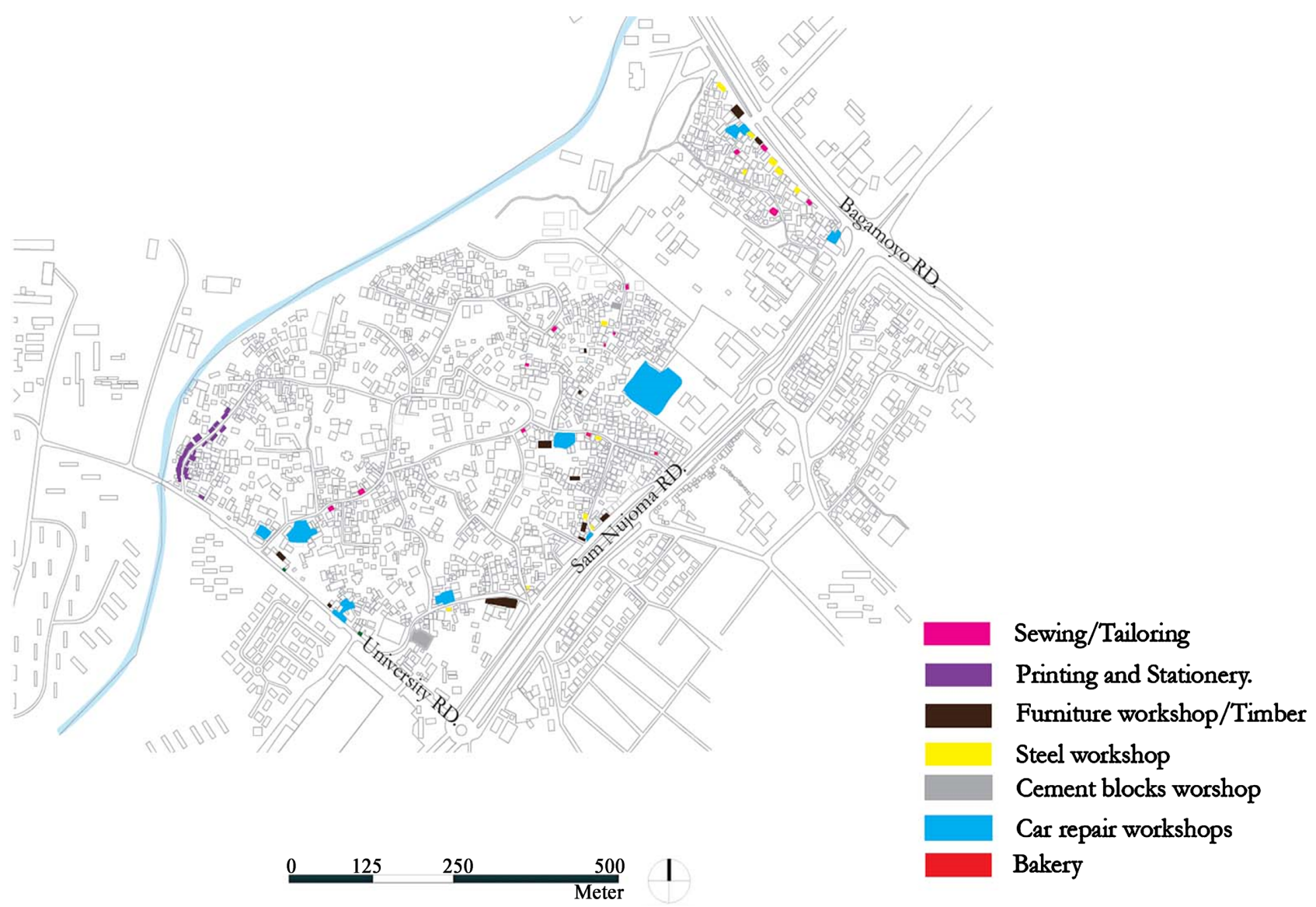

Source: Adopted from ARU-architecture fourth year students of 2019.

Figure 2. Map showing distribution of small-scale industrial areas at Mlalakuwa neighbourhood.

The study revealed that Lufungila and Mpakani along Sam Nujoma road and other areas along Bagamoyo road and has massive collective spaces for Small-Scale industrial activities, and they are located close to the sides of the main roads. These areas have several steel workshops and more than $70 \%$ of Small-Scale industrial activities, taking advantage of the availability of customers and accessibility to other parts of the city (Figure 3(a) and Figure 3(b)). Since the area is having mixed low and middle-income communities, Small-Scale industrial activities grow quite rapid because it becomes an alternative solution to meet the demand of the products needed by local customers at Mlalakuwa and other nearby settlements. SSI operators are self-employed operating from renting space, with others using additional available collective spaces for other functions. SSI has been a part of creating economic infrastructures not only at Mlalakuwa also to other adjacent informal settlements. Many of SSI locations have been training centers for young people who have finished primary schools and don't have the opportunity to further studies in high schools. They engage in SSI activities and get skills, and later they establish other centers at different locations in the city of Dar es Salaam. One of the employees at the Steel workshop narrated: 


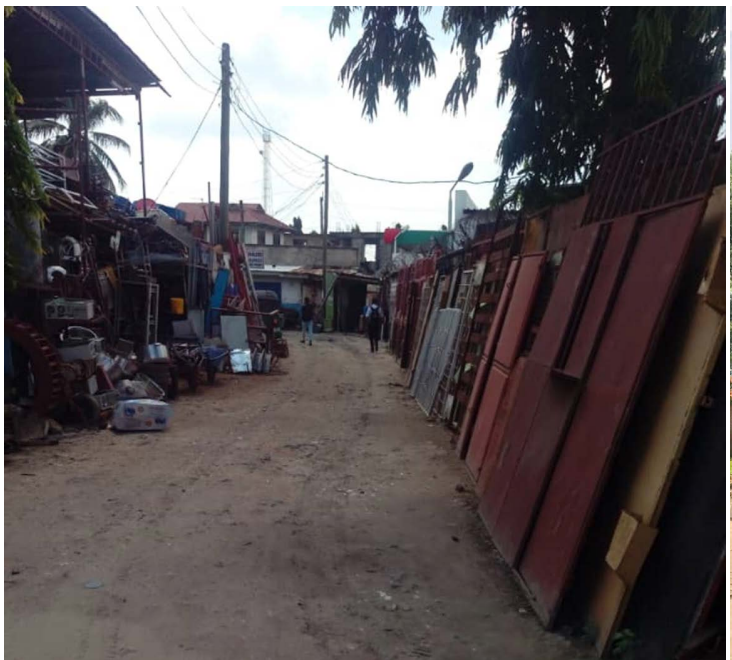

(a)

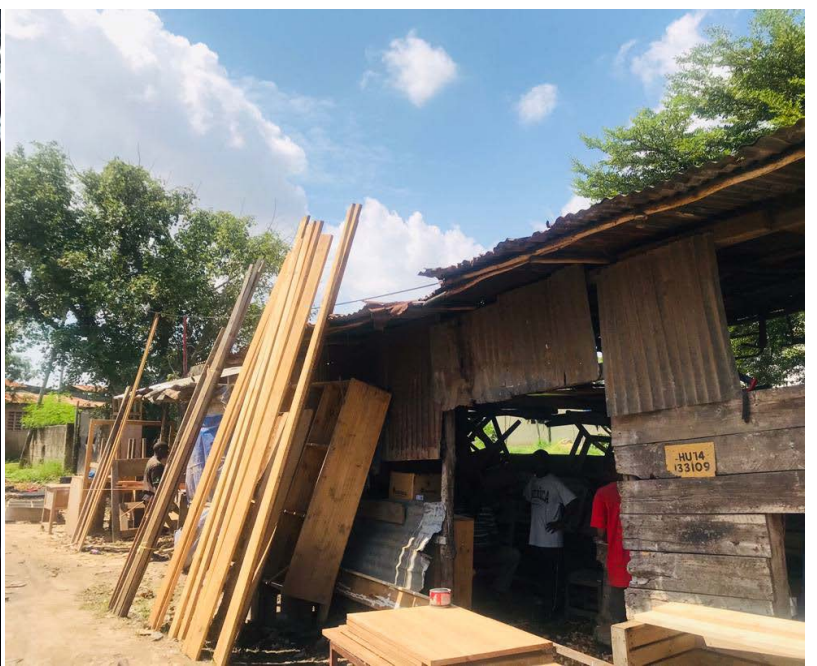

(b)

Source: Fieldwork, 2020.

Figure 3. Distribution of SSI at different streets at the site of the main roads. (a) Teel workshop close to Sam Nujoma Road; (b) Furniture workshop close to Bagamoyo Road.

(...) "I'm planning to have my own workshop later on. I work and learn so hardly to get experience and new ideas, because the customers are well exposed to internet browsing. They bring us images from the internet and ask us to make the same steel furniture that they saw on the internet"s.

This implies that SSI becomes an important self-developed sector which becomes an alternative employment for people who are not employed to formal sectors. This also has been sensitised by politicians that people had to employ themselves as there is insufficient employment opportunities to public sectors. However, young people who practising SSI activities will continue to be given an opportunity by the government to establish themselves including getting loans for the developing their small-scale industrial activities ${ }^{6}$.

Apparently, it was observed that the SSI activities are legally practising at Mlalakuwa because most of them have registered to formal institutions like BRELA ${ }^{7}$ and $\mathrm{TRA}^{8}$ and recognised as low-income earners. SSI seems to have contribution by paying taxes and levies to the government. A narration regarding the SSI operation at Mlalakuwa:

(...) "Most of the SSI operators follow the rules for conducting their activi-

\footnotetext{
${ }^{5} \mathrm{An}$ interview held on May 2021 with a customer at one of the car repair workshop at Mlalakuwa. ${ }^{6}$ Tanzania prime minister speech on April 17, 2021.

${ }^{7}$ The Business Registrations and Licensing Agency (BRELA) has completed the development of a modern Online Registration System (ORS), the system comprises registration of companies, business names, trade and service marks and their respective post registrations, issuance of patents and industrial licenses.

${ }^{8}$ TRA: The Tanzania Revenue Authority is a semi-autonomous Government Agency of the United Republic of Tanzania. It was established by the Tanzania Revenue Act, CAP. 339 in 1995 and started its operations on the 1st of July 1996.
} 
ties at Mlalakuwa area. They pay taxes and levies to the authorities, which is very important for them and the community at large. There is a little slight challenge that I would say to these people. I have some cases against some of these SSI operators as they block streets and give out challenges to other street users. So we, as local authorities, are finding different ways to solve this problem of misusing the streets. I hope that at the end of the day, we are going to have a better solution for that"

\subsection{The Impact of Small-Scale Industries on the Emerging of Collective Spaces}

It was observed that Mlalakuwa is a mixed informal settlement that is dominated by single-story to two stories building typologies, and more than three stories to some commercial buildings along the University and Sam-Nujoma roads (Kalugila \& Mbisso, 2018). However, it has been seen that the front domestic spaces are mostly used for many functions including the operation of Small-Scale industrial activities like sewing and shoemakers were seen to operate in domestic spaces (Figure 4(a)).

Collective spaces surrounded by buildings were converted to garage workshops, sand and cement block workshops, where verandas are quite often converted to offices for garages (Figure 4(b)). On the other hand, buildings collective spaces are converted to car spare shops and parking spaces close to main car repair workshop (Figure 5). Also, these spaces have been used by motorcycle

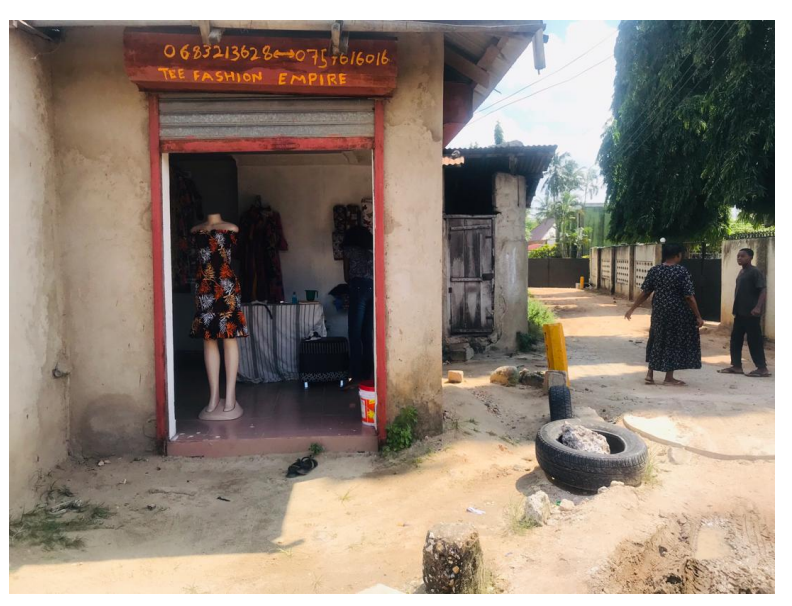

(a)

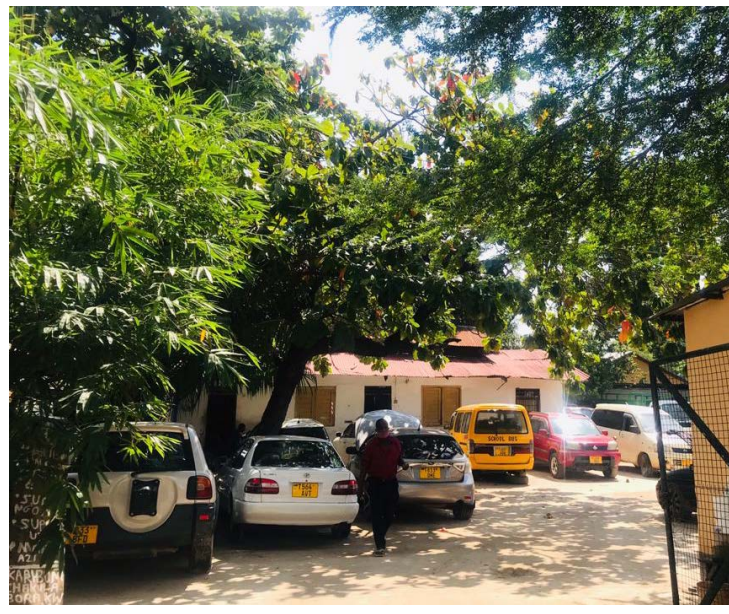

(b)

Source: Fieldwork, 2020.

Figure 4. Showing types of SSI located at domestic spaces. (a) Sewing (tailoring) workshop at front domestic space to interior street at Mlalakuwa neighbourhood; (b) Car repair workshop at domestic space as SSI space utilization capacity.

\footnotetext{
${ }^{9}$ An interview held on May 2021 with MEO who is Mtaa executive officer: An executive officer for Mtaa or street is a part or a division of a ward and includes a part or a division of a township situated within an area under the jurisdiction of an urban authority MEO is appointed by municipal director.
} 


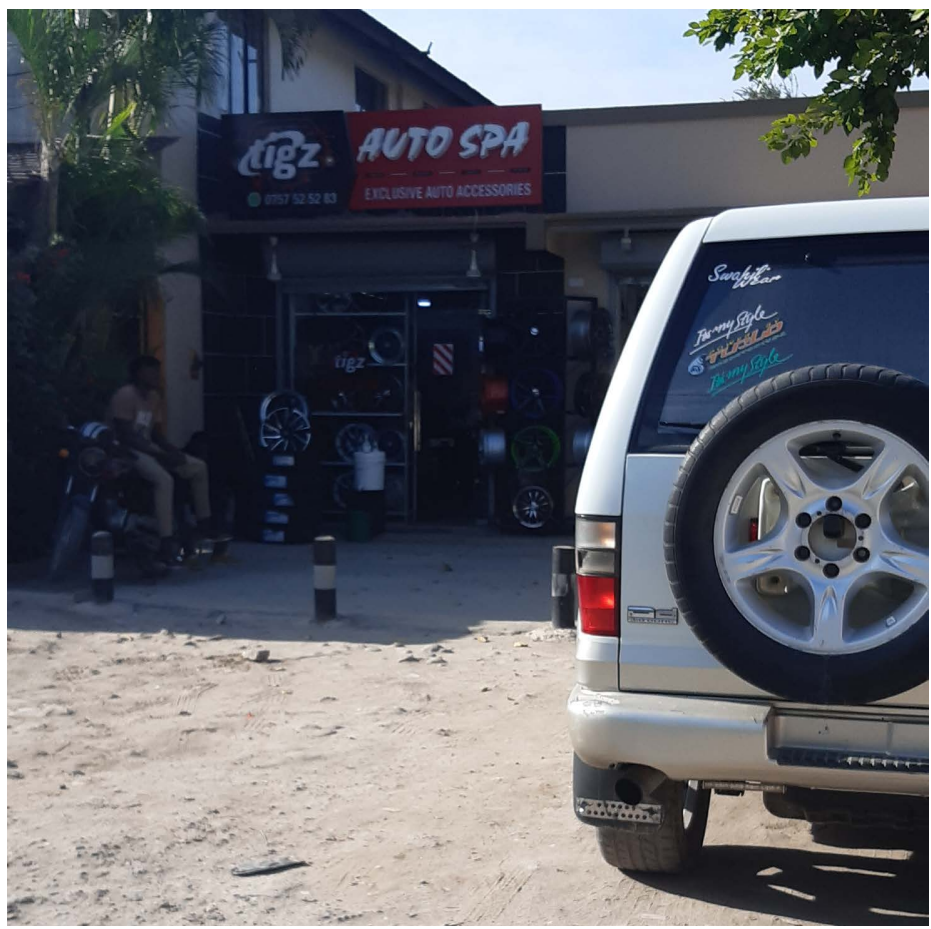

Source: Fieldwork, 2021.

Figure 5. Showing extension of building for car spare shop and parking place adjacent to main car repair workshop at Survey area Mlalakuwa.

operators quite often to wait to pick up car owners who might need a quick transport to other parts of the city while their cars are still in repairing process.

It has been observed that spaces along service roads and pedestrian ways were converted to parking for repaired cars, whereas in some areas, spaces were used as products display areas (Figure 6(a)) and Figure 6(b)). Presence of SmallScale industrial activities at Mlalakuwa changed space use to a great extent. Collective spaces available were converted to adopt the functional and operation of Small-Scale industrial activities. A carpenter found during field observation narrated:

(...) "We have limited spaces here. For instance, we have several activities around us and we need more spaces like a workshop area, storage, an office, and a display area. We have tried to maximize the use of space, but we still we don't have enough space to display our furniture. That's why we are using this pedestrian way as a display area"10.

This implies that SSI activities at Mlalakuwa are the source of collective transformation. As many spaces transformed by reflecting the nature of activities. Other collective spaces along streets adopted to suit a different SSI industrial function. However, the limited space and population increase also have been source for SSI to contribute increase the use of collective spaces at Mlalakuwa.

It was found that more than $40 \%$ of Small-Scale industrial operators responded

${ }^{10} \mathrm{An}$ interview held on June 2021 with carpenter at woodwork shop at Mlalakuwa. 
positively, that more spaces were needed to run their activities. However, $23 \%$ of the residents from adjoining settlements suggested that there is a need for collective spaces for people to interact apart from the existing collective spaces where seem to be the main area for Small-Scale industrial production. And 15\% of employees' respondents suggested common spaces needed for other activities like displaying areas and waiting areas, which are most convenient for the customers (Table 2).

\subsection{Supply Chain and Spatial Development}

Existing literature (Bernstein, 1982; Fiori \& Brandão, 2010) emphasizing the quality of life depends upon social equality in the settlement. It is a moral and social,

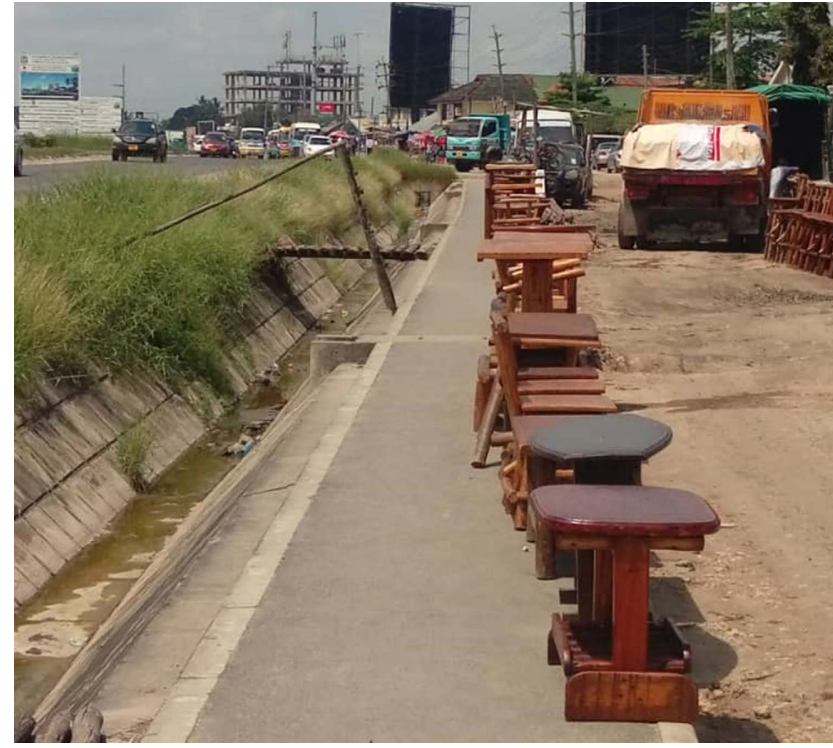

(a)

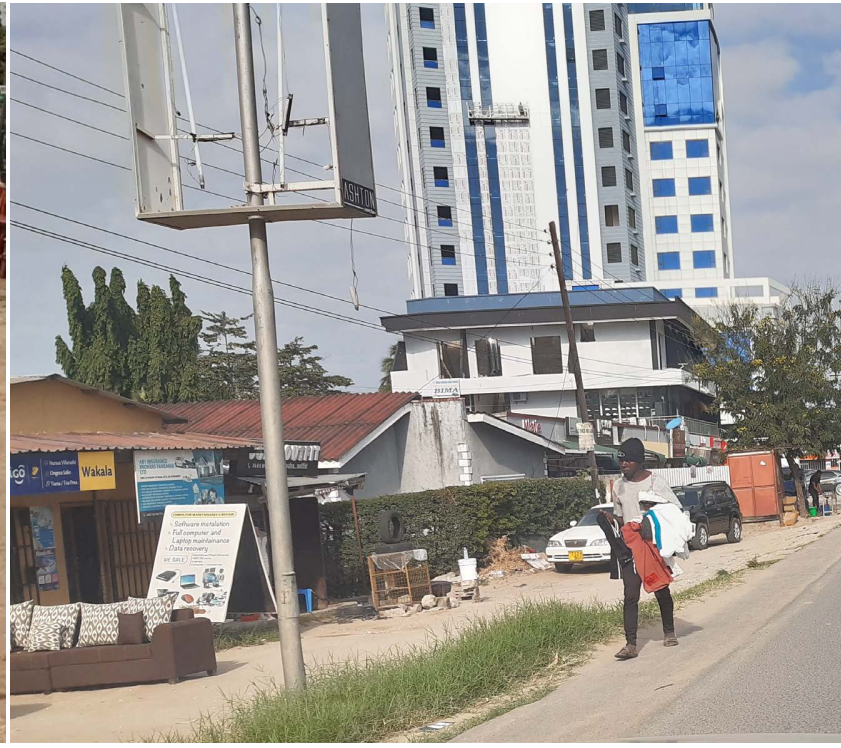

(b)

Source: Fieldwork, 2021.

Figure 6. Showing displaying collective spaces at pedestrian way and on the road reserve areas. (a) Displaying areas at pedestrian way to Bagamoyo Road; (b) Sofa and car serviced laid on road reserve area at University Road.

Table 2. Respondent user group of collective of spaces at small-scale industrial areas.

\section{$\mathrm{S} / \mathrm{N}$ Type of user groups respondents}

Number

interviewed

1 People who run SSI activities observed during fieldwork

Sewing (tailoring), car repair, wood processing and furniture workshop, 21 bakery, steel/welding and cement and sand block workshops

2 Mlalakuwa residents including students Wood processing and furniture workshop, steel/welding, car repair 11

3 Residents from adjoining settlements: Car repair, furniture workshops, steel and wood processing Sinza, Changanyikeni and Makongo

4 Employees from public service, local authority and private sectors

Total

Furniture workshops, car repair, steel and wood processing

8

52

Source: Fieldwork, 2020. 
physical concept that is attained by the goal of being free to eliminate the gap between the rich community and poor communities to encourage development that covers social inequality. Streets and collective spaces have become important economic drivers for spatial development at Mlalakuwa informal settlement neighbourhood.

It has been found that there are two ways economic drivers and networks formed the spatial patterns within the settlements through an examination of the qualitative data. Within the case study area, there are internal and external economic drivers' networks whereby the external supply chain depends on resources like vehicle spares imported from Dubai, China and Japan ${ }^{11}$ and woods mostly from Sao-hill, Mufindi in the Iringa region they are transported to Buguruni area. All resources from the external supply chain were brought to Karia$\mathrm{koo}^{12}$ as the main distribution point of many types of products from abroad and upcountry that are used for SSI sectors in the city of Dar es Salaam (Figure 7(a)) $)^{13}$. Buguruni area also found to be the main distribution point for wood resources

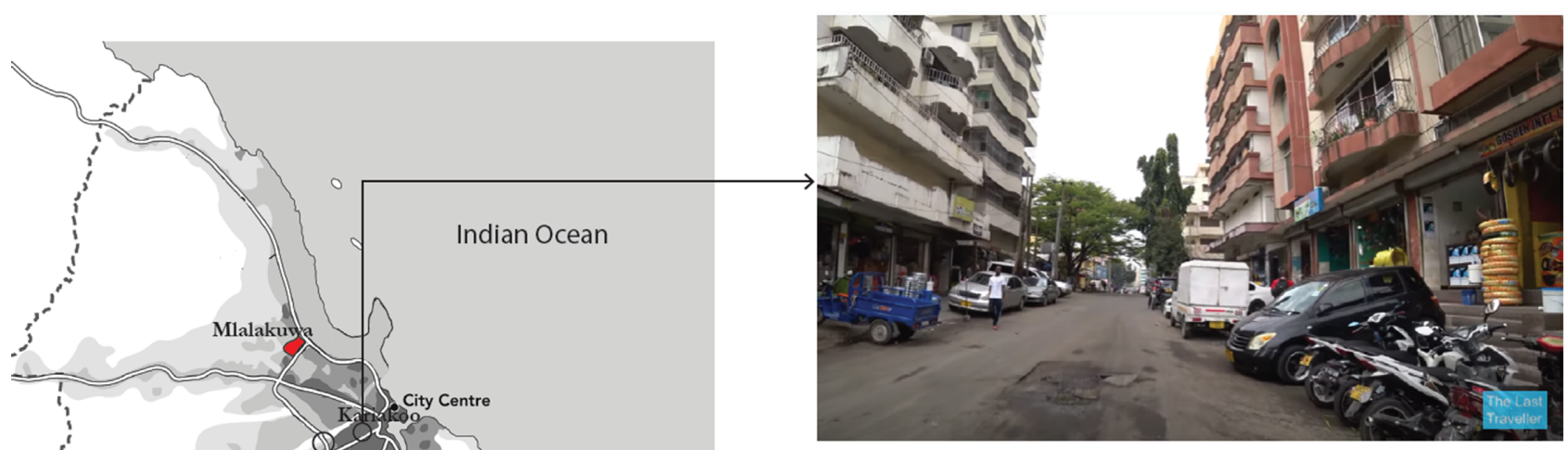

(a) Automobile spare shops and other raw matrials at Kariakoo area

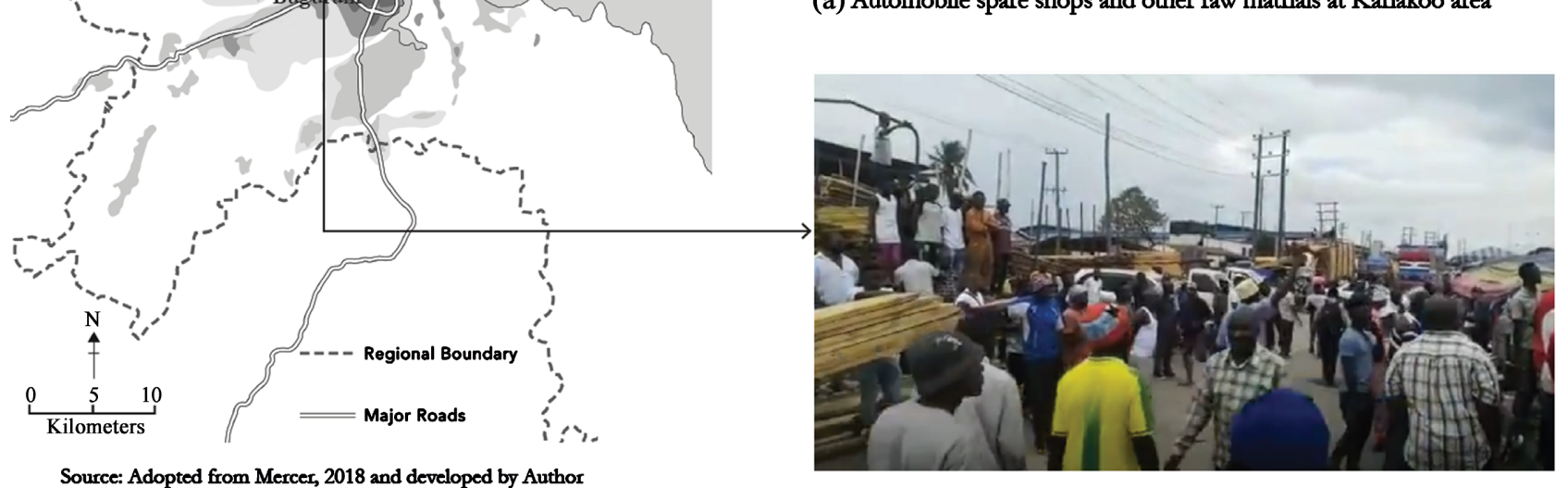

(b) Timber/wood shops and other raw matrials at Buguruni area

Source: Field Survey, 2019.

Figure 7. Some important shops at Kariakoo and Buguruni area for supplying raw materials to Mlalakuwa.

\footnotetext{
${ }^{11} \mathrm{An}$ interview was conducted in February 2020 with one of the owners of the car repair workshop located near sky-mall along university road.

${ }^{12}$ Kariakoo is a ward in the Ilala district of Dar es Salaam, Tanzania. The name derives from a corruption of the British "carrier corps", which used to be based in this area. Today, Kariakoo is mainly known for its extensive market, which spans several city blocks.

${ }^{13}$ An interview was conducted in February 2020 with Mlalakuwa SSI operator.
} 
to Mlalakuwa neighbourhood which enhance the increases spatial development at Mlalakuwa (Figure 7(b)).

The internal supply chains are necessary for processed products like furniture making, at point (a) e.g., steelworks, block works, etc. SSI, such as carpenters, sofa makers, welders-any sorts of trade involving furniture making, follow at point (a) in (Figure 8). However, the places are easily accessible that create dispersed movements of spatial pattern along Samu-Nujoma, Morogoro and Alhassan-Mwinyi roads towards those distribution areas to accelerate and ease the flow of materials to run the Small-Scale industrial activities. There is still vast evidence that the clustering of the furniture making points at all main roads at Mlalakuwa neighbourhood.

Most Small-Scale industries range from carpentry furniture production and tailor production, steel fabrication, vehicle repair, metal doors, windows, etc. The study revealed that $33 \%$ of furniture workshops contribute to a large number of economic activities due to the high demand for products needed by customers. The need of products from this SSI means operational spaces also needed to accommodate all functions. It is clear that operation of Small-Scale Industries,

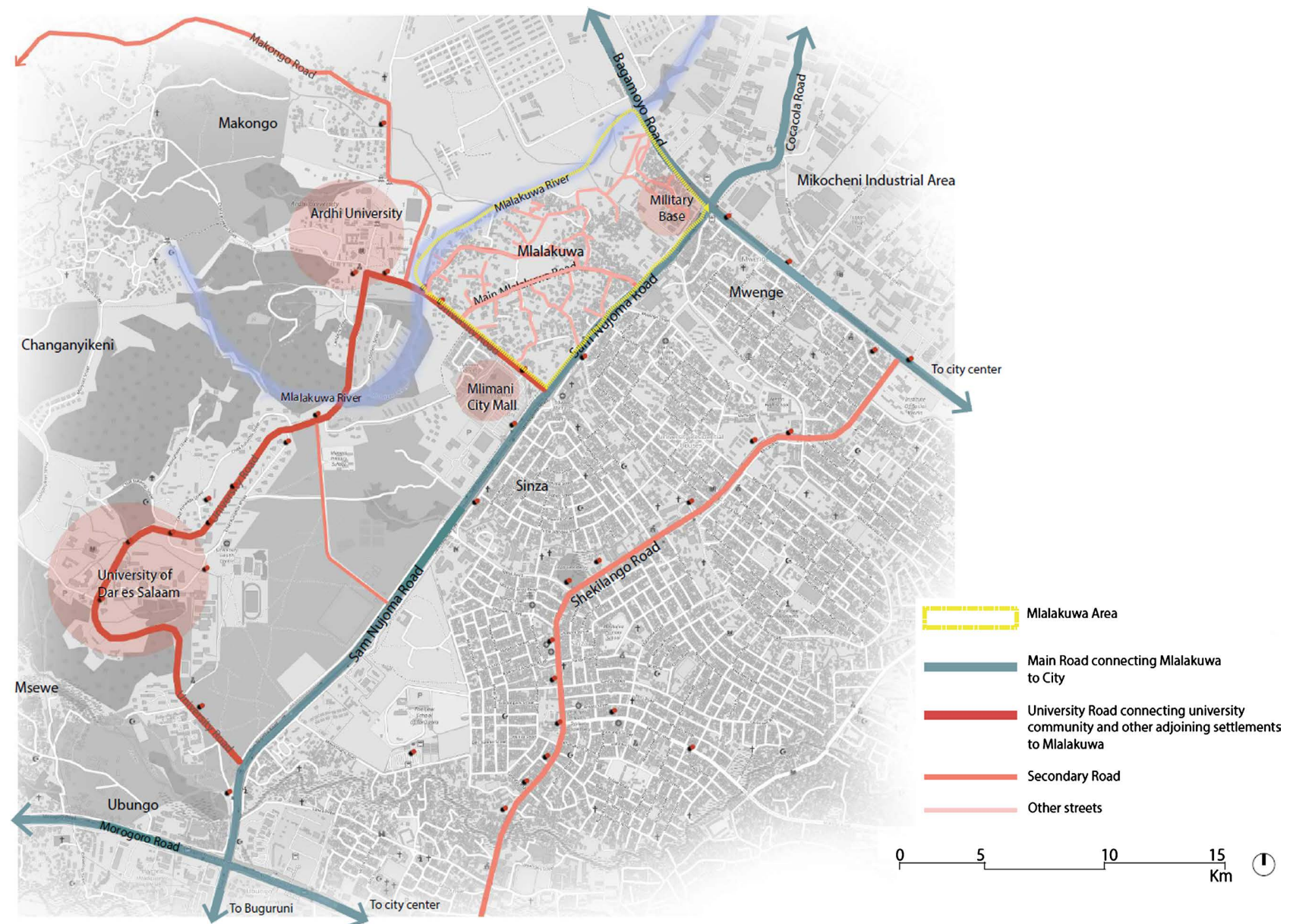

Source: Masters students KU Leuven ELBG1 Urban Projects, Collective Spaces and Local Identities, 2019.

Figure 8. Shows how Mlalakuwa area linked to main roads and other distribution areas from city center. 
is expanding and likely contribute the emerging of collective spaces since the increasing the space usage which will later affect the space value.

\section{Conclusion}

This paper aimed to explore the legibility of SSI in informal settlements and understand the process involved in the formation of the collective space at the Mlalakuwa neighbourhood. Among other empirical regularities, small-scale industrial activities are highly correlated with the city's socioeconomic and physical realities at Mlalakuwa informal settlement. Furthermore, SSI emphasizes the legibility of self-developed activities which model collective space in informal sentiment in many ways. The area is surrounded by major activity clusters, which leads to insufficient public and productive space. The study revealed that small-scale industries are the outcome of the insufficient economic development planning strategy of many developing cities. Despite the effort made to improve the informal areas in the city of Dar es Salaam, small-scale industries have become an important aspect that contributes to the growth of the economy, leading to the growth of urban.

It is important for local authorities and small-scale industrial practitioners to have a great emphasis on identifying the legibility of SSI in informal settlements because they play a great role in changing human lives. Generally speaking, a rationale for policies should be changed that aim directly at shifting ideological perspectives from formal employments to SSI activities. This sector was found to absorb a large number of unemployed communities in formal sectors. The operations of SSI are seen to be a source of collective space transformation where buildings and open collective space are altered to mitigate SSI specifications. However, authorities and development actors should intervene in the rising usage of collective spaces that interfere with the interests of other users which is not perceived as an issue.

\section{Conflicts of Interest}

The authors declare no conflicts of interest regarding the publication of this paper.

\section{References}

Ahmed, S. A. (2006). The Role of SMEs in Developing Economy. Abuja, Omotayo and Co. Ltd.

Aikoye, M. A. (1989). SAP and the Industrial Sector. Ministry of Finance and Economic Planning.

Allen, H. (1977). The Informal Industrial Sector and Growth: Some Thoughts on a Modern Mythology. Institute for Development Studies, University of Nairobi.

Amiri, B. A., \& Lukumwena, N. (2018). An Overview of Informal Settlement Upgrading Strategies in Kabul City and the Need for an Integrated Multi-Sector Upgrading Model. Current Urban Studies, 6, 348-365. https://doi.org/10.4236/cus.2018.63019 
Amiri, P., \& Ghanbari. N. (2016). Investigating Factors Affecting the Formation of Informal Settlements in Iran. Turkish Online Journal of Design, Art and Communication, 637-664. https://doi.org/10.7456/1060JSE/031

Avermaete, T., Hooimeijer, F., \& Schrijver, L. (2006). Urban Formation and Collective Spaces. OASE Journal for Architecture, 71.

Bernstein, H. (1982). Industrialization, Development, and Dependence. In H. Alavi, \& T. Shanin (Eds.), Introduction to the Sociology of "Developing Societies" (pp. 218-235). Palgrave. https://doi.org/10.1007/978-1-349-16847-7 18

Chakrabarti, P. G. D. (2001). Delhi's Ongoing Debate on Informal Settlements and Work Places-Issues of Environmental Jurisprudence. Network-Association of European Researchers.

de Sola Morales, M. (1992). Public and Collective Space. The Urbanization of the Private Sector as a New Challenge. On the Transformation of the Metropolis. OASE, 3-8.

Diochon, M. C. (2003). Entrepreneurship and Community Economic Development. McGillQueens University Press.

Dixon, J. A, Gibbon, D. P., \& Gulliver, A. (2001) Farming Systems and Poverty: Improving Farmers' Livelihoods in a Changing World. Food and Agriculture Organization of the United Nations.

Edusah, S. E. (2013). The Informal Sector, Micro-Enterprises and Small-Scale Industries: The Conceptual Quandary. Journal of Economics and Sustainable Development, 4, 177-186.

Fiori, J., \& Brandão, Z. (2010). Spatial Strategies and Urban Social Policy: Urbanism and Poverty Reduction in the Favelas of Rio de Janeiro. In F. Hernandez, P. Kellet, \& L. Allen (Eds.), Rethinking the Informal City (pp. 181-205). Berghahn Books.

Francis, U. (2009). The Role of Small and Medium Enterprises in the Nigerian Economy. University of Nigeria.

Gaillard, H., \& Beernink, A. (2001). The Urban Informal Manufacturing Sector in Tanzania: Neglected Opportunities for Socioeconomic Development. In A. Szirmai, \& P. Lapperre (Eds.), The Industrial Experience of Tanzania (pp. 318-340). Palgrave Macmillan. https://doi.org/10.1057/9780230524514_15

Halla, F. (2007). A SWOT Analysis of Strategic Urban Development Planning: The Case of Dar es Salaam City in Tanzania. Habitat International, 31, 130-142. https://doi.org/10.1016/j.habitatint.2006.08.001

Henderson, V. (2002). Urbanization in Developing Countries. The World Bank Research Observer, 17, 89-112. https://doi.org/10.1093/wbro/17.1.89

Huchzermeyer, M. (2004). From “Contravention of Laws” to "Lack of Rights": Redefining the Problem of Informal Settlements in South Africa. Habitat International, 28, 333-347. https://doi.org/10.1016/S0197-3975(03)00058-4

ILO (International Labour Organization) (2005a). A Global Alliance against Forced Labour: Report of the Director-General Global Report under the Follow-up to the ILO Declaration on Fundamental Principles and Rights at Work 2005.

ILO (International Labour Organization) (2005b). Decent Work and Poverty Reduction Strategies A Reference Manual for ILO Staff and Constituents.

Jahani, A. (2020) Formalization of Informal Settlements: A Study on Kabul Urban Areas. Current Urban Studies, 8, 446-455. https://doi.org/10.4236/cus.2020.83025

Kalugila, S. L., \& Mbisso, D. A. (2018). Developers' Preferences to Types of Emerging Landed Properties in Informal Urban Settlements: Case of Mlalakuwa-Dar es Salaam. 
International Journal of Development Research, 8, Article ID: 12799.

Kigbu, O. Y., \& Maku A. A. (2015). Development of Small Scale Industries: A Panacea for Economic Growth and Development in Nigeria (A Case Study of Small Scale Enterprises in Nasarawa State). IIARD International Journal of Economics and Business Management, 1, 21-28. https://www.iiardonline.org

King, R., \& Dovey, K. (2013). Interstitial Metamorphoses: Informal Urbanism and the Tourist Gaze. Environment and Planning D: Society and Space, 31, 1022-1040. https://doi.org/10.1068\%2Fd1412

Lupala, A. M. (2002). Peri-Urban Land Management in the Rapidly Growing Cities, the Case of Dar es Salaam. University of Dortmund.

Lutta, J., Schoonjans, Y., \& Lupala, A. M. (2021). The Complexity of Social and Cultural Dynamics in Emerging of Collective Spaces in Unplanned Urbanisation: Learning from Mlalakuwa-Dar es Salaam. Current Urban Studies, 9, 445-463. https://doi.org/10.4236/cus.2021.93028

Magalhaes, F., \& Eduardo, R. (2007) Facing the Challenges of Informal Settlements in Urban Centers: The Re-Urbanization of Manaus, Brazil. Inter-American Development Bank.

Marwa A. K. (2015). Evolution of Informal Settlements Upgrading Strategies in Egypt: From Negligence to Participatory Development. Ain Shams Engineering Journal, 6, 1151-1159. https://doi.org/10.1016/j.asej.2015.04.008

Mbisso, D., \& Kalugila, S. (2018). Trading Facilities and Socio-Spatial Character of Informal Settlements: The Case of Mlalakuwa in Dar es Salaam, Tanzania. Journal of Sustainable Development, 11, 141-148. https://doi.org/10.5539/jsd.v11n2p141

McGranahan, G., \& Brown, D. (2015). The Urban Informal Economy, Local Inclusion and Achieving a Global Green Transformation. Habitat International, 53, 97-105. https://doi.org/10.1016/j.habitatint.2015.11.002

Moshi, H. P. B. (2001). The Impact of Reforms in Tanzania: The Case of Manufacturing Industries. In A. Szirmai, \& P. Lapperre (Ed.), The Industrial Experience of Tanzania (pp. 341-348). Palgrave Macmillan. https://doi.org/10.1057/9780230524514_16

Mtatifikolo, P. F. (1998). Small-Scale Industries, Employment and Earning in Developing Countries: Looking Back at Some Debate Issues. Tanzania Journal of Population Studies and Developments, 6, 135-146.

Mwang'Onda et al. (2018). Industrialization in Tanzania: The Fate of Manufacturing Sector Lies upon Policies Implementations. International Journal of Business and Economics Research, 7, 71-78. https://doi.org/10.11648/j.ijber.20180703.14

Nguluma, H. M. (2003). Housing Themselves: Transformations, Modernisation and Spatial Qualities in Informal Settlements in Dar es Salaam, Tanzania. Ph.D. Dissertation, Infrastruktur.

Obi, N. J. (2015). The Role of Small-Scale Enterprises in the Achievement of Economic Growth in Nigeria. International Journal of Social Sciences and Humanities, 3, 1-26.

Ogundiji, B. D. (2006). Achieving the Millennium Development Goals in Nigeria: Regularising Informal and Illegal Settlements in Ibadan. MSc Dissertation, Department of Urban and Regional Planning, University of Ibadan.

Onibokun, A. G., Olokesusi, F., \& Egunjobi, L. (Eds.) (1987). Urban Renewal in Nigeria. NISER/CURP Urban and Regional Planning Series, Ibadan.

Osei-Boateng, C., \& Ampratwum, E. (2011). The Informal Sector in Ghana. FriedrichEbert-Stiftung.

Pacione, M. (2001). Models of Urban Land Use Structure in Cities of the Developed 
World. Geography, 86, 97-119.

Scheerlinck, K. (2013) Collective Spaces Streetscape Territories Notebook. Streetscape Territories Notebooks, Vol. 2, LUCA School of Arts.

Schmidt-Traub, G. (2015). Investment Needs to Achieve the Sustainable development Goals: Understanding the Billions and Trillions. United Nations Sustainable Development Solutions Network.

https://irp-cdn.multiscreensite.com/be6d1d56/files/uploaded/151112-SDG-Financing-Ne eds.pdf

Schoonjans, Y., \& Zhang, Y. (2020). Jiti Kongjian de Lilun Fazhan ji qi yu Chengshi Shenghuo de Xianghu Zuoyong [Interview with Yves Schoonjans: Theoretical Development of Collective Spaces and Its Interplay with Urban Life]. Beijing Planning Review, 194, 191-192.

Selltiz, C., Jahoda, M., Deutsch, M., \& Cook, W. S. (1997). Research Methods in Social Relations. Holt, Rinehart and Winston, Inc.

Shand, W., Colenbrander, S., Mitlin, D., Weru, J., Ratanachaichan, N., Neureiter, K. et al. (2017). Enabling Private Investment in Informal Settlements: Exploring the Potential of Community Finance. Infrastructure and Cities for Economic Development, UK Aid.

Sheuya, S. (1997). Employment-Intensive Upgrading of Urban Unplanned Settlements by Communities-Practices and Opportunities in Dar es Salaam, Tanzania. International Labour Organization.

Skarstein, R., \& Wangwe, S. M. (1986). Industrial Development in Tanzania. Some Critical Issues. Scandinavian Institute of African Studies, Uppsala in Cooperation with Tanzania Publishing House.

Tesha, D. N. G. A. K. (2020). Households Livelihoods Coping Strategies in the Urban Informal Settlements the Case of Mlalakuwa, Dar es Salaam-Tanzania. The International Journal of Social Sciences and Humanities Invention, 7, 6046-6075. https://doi.org/10.18535/ijsshi/v7i07.05

Teyanga, J., \& Mrema, K. M. (2018). Residents' Elements of Legibility of Informal Settlements The Case of Mlalakuwa Informal Settlement in Dar es Salaam-Tanzania. World Journal of Research and Review (WJRR), 6, 66-79.

UN-Habitat (2016). World Cities Report 2016: Urbanization and Development. United Nations Human Settlements Programme.

United Republic of Tanzania (URT) (2013) Population and Housing Census: Population Distribution by Administrative Areas. National Bureau of Statistics, Ministry of Finance, Dar es Salaam and Office of Chief Government Statistician, President's Office, Finance, Economy and Development Planning, Zanzibar.

United Nations Environment Programme (UNEP) (2016). Promoting the Participation of Small and Medium Size Enterprises (SMEs) in Green Public Procurement.

Wijaya, S., Wahyudi, W., Kusuma, C., \& Sugianto, E. (2019). Travel Motivation of Indonesian Seniors in Choosing Destination Overseas. International Journal of Culture, Tourism and Hospitality Research, 12, 185-197. https://doi.org/10.1108/IJCTHR-09-2017-0095 